\title{
LEKSIKON GEJALA COVID-19 DALAM BAHASA-BAHASA BIDAYUHIK DI KALIMANTAN BARAT
}

Lexicon of COVID-19 Symptoms in Bidayuhic Languages at West Kalimantan

\author{
Agus Syahrani ${ }^{a}$, Dedy Ari Asfar ${ }^{b}$, Syarifah Lubna $^{c}$ dan Binar Kurniasari Febriantid \\ ${ }^{a}$ Universitas Tanjungpura \\ Jalan Prof. Dr. H. Hadari Nawawi, Kota Pontianak, Kalimantan Barat, Indonesia \\ b,c,dBalai Bahasa Provinsi Kalimantan Barat \\ Jalan Jenderal Ahmad Yani, Kota Pontianak, Kalimantan Barat, Indonesia \\ agussyahrani@fkip.untan.ac.id
}

\begin{abstract}
Naskah Diterima Tanggal 1 Maret 2021-Direvisi Akhir Tanggal 22 September 2021-Disetujui Tanggal 12 Desember 2021 doi: https://doi.org/10.26499/rnh/v10i2.4068
\end{abstract}

\begin{abstract}
Abstrak
Penelitian ini bertujuan mendeskripsikan bentuk-bentuk leksikon gejala Covid-19 dalam bahasa-bahasa Bidayuhik yang ada di Kalimantan Barat, seperti Dayak Hibutn, Bidayuh, Bakati' Palayo, dan Kerambai. Jenis penelitian ini adalah kualitatif. Tulisan ini menggunakan studi kepustakaan dan metode simak dan cakap dalam memperoleh data. Teknik yang digunakan dalam pengumpulan data dilakukan dengan pencatatan ortografis dan fonetis. Metode yang digunakan untuk menganalisis data adalah metode padan referensial dan translasional. Hasil penelitian ini menunjukkan bahwa penutur Bidayuhik di Kalimantan Barat memiliki leksikon tersendiri dalam penamaan gejala Covid-19. Leksikon penamaan gejala Covid-19 ini berbentuk satu leksem dan gabungan kata. Terdapat perbedaan penamaan gejala COVID-19 antarbahasa Bidayuhik dalam mengidentifikasi istilah penyakit, seperti batuk, influenza, sakit perut, dan penyakit pernapasan.
\end{abstract}

Kata kunci: leksikon, penyakit, gejala Covid-19, Bidayuhik

\begin{abstract}
This study aims to describe the lexical forms of Covid-19 symptomps in Bidayuhik languages in West Kalimantan, such as Dayak Hibutn, Bidayuh, Bakati' Palayo, and Kerambai. This type of research is qualitative. The technique used in collecting data are note taking, interview, and study of literature. The technique used in data collection is done by orthographic and phonetic transcripstion. The method used to analyze data is a referential and translational equivalent method. The results of this study indicate that Bidayuhik speakers in West Kalimantan have their own lexicon in naming Covid-19 symptoms. The lexical naming of Covid-19 symptomps are in the form of a lexeme and a combination of words. There are differences in the naming of Covid-19 symptoms between Bidayuhik languages in identifying disease terms, such as cough, influenza, stomach ache, and pneumonia.
\end{abstract}

Keywords: lexicon, disease, Covid-19 symptoms, Bidayuhi

How to Cite: Syahrani, Agus, dkk. (2021). Leksikon Gejala Covid-19 dalam Bahasa-Bahasa Bidayuhik di Kalimantan Barat. Ranah: Jurnal Kajian Bahasa, 10(2), 341-353. doi: https://doi.org/10.26499/rnh/v10i2.4068

\section{PENDAHULUAN}

Coronavirus Disease 2019 (Covid-19) menjadi narasi penting kesehatan masyarakat global saat ini. Covid-19 dinyatakan sebagai darurat kesehatan masyarakat global oleh World Health 
Organization (WHO) pada 30 Januari 2020. Selanjutnya, narasi mengenai kasus Covid-19 ini terus meningkat secara signifikan sebagai pandemi di berbagai belahan dunia termasuk di Indonesia. Hal ini menjadikan Covid-19 ditetapkan sebagai bencana di Indonesia. Bahkan, pandemik Covid-19 termasuk bencana nasional yang dipertegas melalui Keputusan Presiden Nomor 12 Tahun 2020 tentang Penetapan Bencana Nonalam Penyebaran Covid-19 sebagai Bencana Nasional, ditetapkan pada tanggal 13 April 2020.

Covid-19 begitu cepat menginfeksi manusia, baik melalui kontak fisik secara langsung maupun tidak langsung, bergantung pada tingkat imunitas penderita. Umumnya, gejala COVID-19 menunjukkan gangguan pernapasan akut, seperti demam, sesak napas, dan batuk kering. Gejala-gejala tersebut muncul ketika tubuh bereaksi melawan koronavirus (Pratiwi, 2020).

Menurut Zhe Xu dkk (2020) Covid-19 menjadi pemicu utama dari beberapa penyakit pernapasan yang mematikan manusia. Covid-19 memperlihatkan indikasi infeksi saluran pernapasan yang menyebabkan pneumonia (infeksi saluran pernapasan yang mengenai jaringan paru di paru-paru). Indikasi ini ditandai dengan panas badan, disertai batuk kering hingga menyebabkan keadaan sesak yang menyebabkan Acute Respiratory Distress Syndrome (ARDS) atau gagal napas. Gejala Covid-19 ini dalam konteks multietnik di Indonesia tentu diungkapkan dengan beragam istilah. Artinya, masyarakat multietnik di Indonesia memiliki leksikon tersendiri untuk mengidentifikasi gejala Covid-19. Malangnya, dokumentasi ilmiah mengenai istilah gejala Covid-19 ini dalam bahasa daerah belum terpublikasi. Dapat dikatakan bahwa identifikasi leksikon gejala Covid-19 dalam bahasa-bahasa daerah belum dilakukan secara komprehensif.

Penelitian yang berkenaan dengan konsep penyakit dalam bahasa lokal dapat dilihat dalam Almos (2015) yang mengkaji leksikon pengobatan tradisional Minangkabau. Kajian etnomedisin leksikon pengobatan tradisional Minangkabau yang dilakukan Almos mengemukakan tiga kelompok leksikon pengobatan, yaitu jenis-jenis penyakit, jenis-jenis ramuan, dan leksikon proses pengobatan. Pada kelompok jenis-jenis penyakit contoh leksikon yang ditemukan adalah biriang, tinggam, dan sijundai. Pada kelompok jenis-jenis ramuan leksikon yang digunakan di antaranya adalah limau, injuang, ayam, air, dan batu. Pada kelompok proses pengobatan ditemukan leksikon manyilau dan paureh.

Penelitian yang sama pernah dilakukan Sakinah (2016) tentang leksikon nama penyakit dalam bahasa Melayu dialek Sekadau di Desa Peniti, Kecamatan Sekadau Hilir, Kabupaten Sekadau, Kalimantan Barat. Sakinah menemukan 101 leksikon penyakit dengan mendeskripsikan 7 leksikon penyakit perempuan, 5 leksikon penyakit laki-laki, 7 leksikon penyakit anak-anak, dan 83 penyakit umum yang bisa diderita perempuan dan laki-laki pada usia anak-anak dan dewasa.

Fuadah melalui kajian etimologi dan semantik juga melakukan penelitian terkait istilahistilah penyakit, yaitu penyakit kulit dan kelamin pada masyarakat Jawa, Desa Tegal Pare, Kecamatan Muncar, Kabupaten Banyuwangi. Fuadah menemukan istilah lokal berupa kata asal, frasa, kata berimbuhan, kata majemuk, dan berupa singkatan yang tidak hanya berasal dari bahasa Jawa, tetapi juga berasal dari bahasa Jawa Kuno, Sanskerta, Prancis, dan Latin (Fuadah, 2016).

Penelitian serupa juga dilakukan Fatmawaty dkk (2018) yang mengaplikasikan rapid ethnography terhadap masyarakat Bugis di Kabupaten Sidrap. Fatmawaty dkk menemukan delapan belas nama penyakit pada anak berdasarkan ciri yang tampak pada badan anak, gejala yang ditimbulkan penyakit, dan bagian tubuh yang sakit; penyebab penyakit, baik secara naturalistik maupun personalistik.Pencegahan dan pengobatan penyakit yang dilakukan menggunakan campuran minyak, obat-obat herbal, jampi-jampi, atau pijat. 
Tulisan mengenai leksikon gejala Covid-19 dalam masyarakat etnik penting dilakukan untuk menjelaskan terminologi lokal secara kebahasaan. Tulisan seperti ini juga berfungsi sebagai usaha memahami budaya dan konsep sakit pada masyarakat etnik, di antaranya pada penutur Bidayuhik di Kalimantan Barat. Selain itu, identifikasi leksikon penyakit yang menjadi gejala Covid-19 dalam bahasa Bidayuhik merupakan suatu usaha untuk mengenal daya ungkap bahasa Bidayuhik terhadap pandemik yang menghantam dunia saat ini.

Menurut Asfar (2014 dan 2015) bahasa Bidayuhik merupakan penamaan bahasa yang dikenalkan James T. Collins untuk mengidentifikasi dan mengklasifikasi bahasa-bahasa di Kalimantan Barat yang secara fonologis memiliki persamaan retensi dan inovasi MelayuPolinesia Purba (BMPP)*1 dan *R. Artinya, dalam perspektif linguistik bandingan historis ciciciri fonologi bentuk bahasa Melayu-Polinesia Purba (BMPP)*l dan *R berkorespondensi menjadi l:r:y:h:y:Ø dalam bahasa Bidayuhik. Oleh karena itu, secara linguistik bahasa Bidayuhik ini merupakan penamaan untuk suku-suku Dayak, seperti Bakati', Bidayuh, Ribun/Hibutn, Kembayan, Semandang, Pruwan, dan Menentukan (lihat Chong Shin, 2008; Rensch, 2012; Asfar, 2014 dan 2015; Collins, 2021) karena *1 dan *R berkorespondensi menjadi 1:r:y:h:y:Ø. Bahkan, bahasa Bidayuhik merupakan salah satu kelompok besar bahasa yang populasi penuturnya tidak hanya di Kalimantan Barat, tetapi juga di Sarawak, Malaysia.

Penelitian tentang nama-nama penyakit dalam bahasa Bidayuhik belum pernah dilakukan. Malahan, penelitian nama gejala Covid-19 pada para penutur Bidayuhik pun tidak disinggung dalam penelitian yang telah ada. Penelitian terhadap bahasa Bidayuhik yang ada di Kalimantan Barat lebih banyak dilakukan dalam mendeskripsikan hubungan kekerabatan dan klasifikasi kelompok bahasa Bidayuhik di Kalimantan Barat. Misalnya, penelitian Asfar (2014 dan 2015) menggambarkan pemetaan dan kekerabatan bahasa Bidayuhik yang ada di Tayan Hulu, Kabupaten Sanggau. Ada juga penelitian Bidayuhik di sepanjang aliran Sungai Sekadau yang dilakukan oleh Chong Shin dan Collins (2008) dengan memetakan enam varian Bidayuhik di Kabupaten Sekadau. Penelitian serupa juga dilakukan Rensch (2012) dengan menganalisis tata bunyi Bidayuh, baik secara diakronis maupun sinkronis. Rensch (2012) berhasil memetakan dan mengelompokkan suku-suku lokal, seperti Bakati', Ribun, Bidayuh, Kembayan, dan Semandang di Kalimantan Barat serta Bukar-Sadung, Siburan-PenrissenPadawan, Sembaan-Tringgus yang ada di Sarawak, Malaysia sebagai kelompok bahasa Bidayuh di Pulau Borneo. Penelitian lain tentang bahasa Bidayuhik juga pernah dijalankan Asfar (2016) dengan menggambarkan Bemak sebagai salah satu varian bahasa Bidayuhik yang ada di Kabupaten Landak.

Berdasarkan beberapa penelitian di atas dapat disimpulkan dua hal penting. Pertama, penelitian bahasa yang berkenaan dengan penamaan penyakit dalam bahasa daerah cukup diminati, tetapi masih belum menampilkan leksikon gejala Covid-19. Kedua, penelitian bahasa Bidayuhik berhubungan dengan istilah penyakit belum pernah dilakukan. Dengan demikian, penelitian leksikon gejala Covid-19 dalam bahasa Bidayuhik masih belum terdokumentasi.

Tulisan dalam artikel ini membahas bagaimana bentuk-bentuk leksikon gejala Covid-19 dan mendeskripsikan bentuk-bentuk leksikon gejala Covid-19 dalam bahasa Bidayuhik yang ada di Kalimantan Barat. Adapun bahasa Bidayuhik yang menjadi objek tulisan ini adalah Dayak Hibutn, Bidayuh, Bakati' Palayo, dan Kerambai. Tulisan ini menjadi catatan penting sebagai usaha preservasi bahasa etnik lokal agar dikenal khalayak akademik dan masyarakat umum. Selain itu, kajian ini penting sebagai sumbangsih dalam bidang leksikologi dan leksikografi (perkamusan) bahasa daerah berkenaan dengan penamaan nama penyakit. 


\section{LANDASAN TEORI Konsep Leksikon}

Leksikon menurut Crystal (2008) dalam arti yang paling umum merupakan istilah yang identik dengan kosakata. Kamus dapat dilihat sebagai satu set entri leksikal yang mengandung leksikon. Definisi ini senada dengan pengertian yang ada dalam Kamus Besar Bahasa Indonesia (KBBI). KBBI daring mendefinisikan "leksikon" ke dalam enam makna berpolisemi. Keenam makna tersebut adalah (1) kosakata, (2) kamus yang sederhana, (3) daftar istilah dalam suatu bidang disusun menurut abjad dan dilengkapi dengan keterangannya, (4) komponen bahasa yang memuat semua informasi tentang makna dan pemakaian kata dalam bahasa, (5) kekayaan kata yang dimiliki suatu bahasa, dan (6) pemrograman, pengidentifikasi, kata kunci, konstanta, dan unsur-unsur lain dari bahasa yang membentuk kosakatanya. Oleh karena itu, leksikon memiliki peran sangat penting dalam tata bahasa leksikal-fungsional.

Lebih lanjut Crystal (2008) mengungkapkan satuan kosakata adalah umumnya disebut sebagai item leksikal, atau leksem. Butir leksikal dari suatu bahasa merupakan kamus bahasa itu, atau leksikon sebuah istilah. Butir yang terdaftar 'di leksikon' merupakan sebagai satu set entri leksikal. Cara item leksikal diatur dalam suatu bahasa adalah struktur leksikal atau sistem leksikal. Sekelompok item yang digunakan untuk mengidentifikasi jaringan dalam bidang semantik atau leksikal tertentu (mis. memasak, warna) juga dapat disebut 'sistem leksikal'.

Berdasarkan beberapa konsep mengenai leksikon dapat disimpulkan bahwa leksikon merupakan kosakata yang memiliki makna tersendiri atau kekayaan kata yang dimiliki suatu bahasa. Leksikon merupakan sebagai istillah tertentu yang ada dalam sebuah bahasa. Hal ini senada dengan yang dikemukakan Suleiman dalam Spolsky (1999) mengemukakan leksikon itu sangat penting dikumpulkan dan dikembangkan sebagai sumber daya leksikal bahasa. Manfaat pengembangan leksikon ini di antaranya untuk (1) membuat istilah baru; (2) menggunakan istilah tidak umum digunakan untuk menunjuk konsep yang baru atau penemuan; (3) memperluas ruang lingkup semantik kata yang ada untuk menunjuk konsep baru atau penemuan; (4) terjemahan pinjaman atau parafrase.

\section{Penamaan Gejala Covid-19}

Kasus Covid-19 muncul pertama kali di Wuhan, Provinsi Hubei, China. Awal kemunculannya diduga merupakan penyakit pneumonia, dengan gejala serupa sakit flu pada umumnya (Ying-Ying Zheng, 2020). Gejala tersebut di antaranya batuk, demam, letih, sesak napas, dan tidak nafsu makan. Namun, menurut Mona,berbeda dengan influenza, koronavirus dapat berkembang dengan cepat hingga mengakibatkan infeksi lebih parah dan gagal organ serta kematian (Sari dkk, 2020).

Isngadi dkk (2020) mengemukakan tanda dan gejala umum infeksi Covid-19 antara lain gejala gangguan pernapasan akut seperti demam, batuk, dan sesak napas. Penyakit ini terutama menyebar dari orang ke orang melalui droplet saat batuk dan bersin. Virus ini dapat bertahan hingga 3 hari dalam plastik atau stainlesssteel dan 3 jam pada aerosol. Mahrania dkk mencatat ada juga pasien Covid-19 yang mengalami nyeri tenggorokan tanpa gejala lainnya. Sehari setelah pemeriksaan swab, pasien mulai demam, mual, lemas, dan buang air besar (Mahrania dkk, 2020).

Yuliana juga mencatat gejala utama Covid-19, seperti demam, batuk, dapat disertai dengan nyeri tenggorok, kongesti hidung, malaise 'tidak enak badan', sakit kepala, dan nyeri otot (Yuliana, 2020). Zendrato mengatakan bahwa gejala Covid-19 ini berbentuk batuk kering dan diikuti dengan gangguan pernafasan serta kehilangan indera penciuman dan perasa (Zendrato, 2020).

Pendapat serupa juga dikemukakan Aida (2020) dan Fathoni (2019) bahwa ada beberapa gejala Covid-19, yaitu sesak napas, demam, batuk kering, menggigil, tubuh merasa sakit, bibir 
biru, sulit bernapas, nyeri dada, diare, gejala konjungtivitis atau mata merah muda, kehilangan bau dan rasa, kelelahan, sakit kepala, sakit tenggorokan, dan hidung tersumbat. Lebih lanjut, Aida (2020) yang mengutip Center for Disease Control and Prevention (CDC) atau Pusat Pengendalian dan Pencegahan Penyakit Amerika Serikat telah menjabarkan tanda-tanda darurat lain saat terinfeksi Covid-19. Menurut Fathoni (2019) tanda-tanda darurat itu adalah rasa sakit terus-menerus atau tekanan di dada, bibir atau wajah menjadi kebiruan.

Teori berkenaan dengan leksikon gejala Covid-19 di atas mendeskripsikan penamaan penyakit yang lazim dalam kehidupan manusia sehari-hari. Istilah gejala Covid-19 itu di antaranya diare, demam, batuk kering, menggigil, tubuh merasa sakit, bibir biru, sulit bernapas, nyeri dada, diare, gejala konjungtivitis atau mata merah muda, kehilangan bau dan rasa, kelelahan, sakit kepala, sakit tenggorokan, hidung tersumbat, rasa sakit terus-menerus atau tekanan di dada, serta bibir atau wajah menjadi kebiruan. Dengan demikian, gejala Covid-19 seperti yang dijelaskan tersebut menjadi dasar untuk mendeskripsikan istilah lokal dalam bahasa Bidayuhik dengan menggunakan metode analisis padan referensial dan translasional.

\section{METODE PENELITIAN}

Bentuk penelitian ini merupakan kualitatif. Menurut Raco penelitian kualitatif merupakan model kerja terlibat langsung untuk mencari arti (meaning) dan mengerti (understanding) gejala, peristiwa, fakta, dan realitas yang terjadi. Peneliti dapat menanyakan pertanyaan yang tepat kepada partisipan dan menangkap pengertian mereka tentang gejala, peristiwa, fakta, realitas, perasaan, dan persepsi mereka (Raco, 2010).

Penelitian kualitatif dalam tulisan ini menggunakan studi kepustakaan dan metode simak dan cakap dalam memperoleh data. Menurut Zaim (2014) studi kepustakaan merupakan suatu tahapan yang penting dalam rangkaian kegiatan penelitian bahasa untuk mengetahui sampai sejauh mana ilmu yang berhubungan dengan penelitian yang akan dilakukan itu telah berkembang, dan sampai di mana penelitian-penelitian yang berkaitan dengan itu telah dilakukan orang. Dengan kata lain, menelusuri literatur yang ada dan menelaahnya dengan teliti merupakan kerja kepustakaan yang sangat diperlukan dalam mempersiapkan penelitian (Zaim, 2014). Dengan studi kepustakaan peneliti menguraikan hasil-hasil penemuan atau teori yang berkaitan dengan masalah yang digarap (Zaim, 2014).

Metode simak merupakan pengumpulan data yang dilakukan melalui proses penyimakan atau pengamatan terhadap penggunaan bahasa yang diteliti, sedangkan metode cakap merupakan pemerolehan data dengan melakukan percakapan antara peneliti dan penutur bahasa selaku informan (Zaim, 2014).

Teknik yang digunakan dalam pengumpulan data adalah teknik catat. Pencatatan dilakukan berupa pencatatan ortografis dan fonetis. Peneliti juga menggunakan teknik cakap tansemuka (CTS) dengan melakukan percakapan, baik secara lisan maupun tertulis. Dalam hal ini, peranan peneliti sebagai pemancing pembicaraan diganti dengan daftar pertanyaan (Zaim, 2014).

Objek penelitian ini adalah bahasa Bidayuhik yang dipakai oleh penutur Dayak pada dua kabupaten yang ada di Kalimantan Barat, yaitu Bengkayang dan Sanggau. Oleh karena itu, populasi penelitian ini adalah semua tuturan Bidayuhik dengan aspek-aspek linguistiknya. Berkenaan dengan populasi tersebut, sampel yang dipilih adalah tuturan Bidayuhik yang terdapat dalam masyarakat Dayak Bakati' Palayo di Kampung BTN Rangkang Sekayok Permai, Kecamatan Sebalo dan Dayak Bidayuh di Kampung Lawang, Kecamatan Siding, Kabupaten Bengkayang, serta Dayak Hibutn yang ada Kampung Binjai, Kecamatan Tayan Hulu dan Dayak Kerambai yang ada di Kampung Masa Selangai, Kecamatan Sekayam, Kabupaten Sanggau. 
Metode yang digunakan untuk menganalisis data adalah metode padan. Metode padan yang digunakan adalah metode padan referensial dan translasional.Metode referensial alat penentunya adalah referen (reference), yaitu kenyataan yang ditunjuk oleh bahasa. Referen bahasa dalam penelitian ini adalah nama-nama gejala Covid-19 yang dijelaskan secara sinonimi dan leksikografis. Metode translasional alat penentunya adalah bahasa atau langue lain, misalnya bahasa Inggris dan Indonesia. Penggunaan bahasa lain adalah untuk memberi tuntunan atau pedoman dengan membandingkannya dengan bahasa yang diteliti. Padanan unsur lingual tertentu dari bahasa yang sudah dikenal dengan unsur bahasa yang diteliti akan memberi informasi sementara tentang perilaku unsur bahasa yang diteliti (Zaim, 2014). Oleh karena itu, dalam penelitian ini sistem satuan lingual bahasa tertentu, yaitu penamaan gejala Covid-19 dalam bahasa Inggris dan Indonesia diperikan dalam kerangka sistem bahasa Bidayuhik. Gejala Covid-19 dalam bahasa-bahasa Bidayuhik yang dibahas dalam tulisan ini berjumlah sembilan leksikon. Kesembilan leksikon tersebut adalah batuk, influenza, pernapasan, sakit perut, dan lima leksikon gejala lain, antara lain bibir dan wajah kebiruan, kebingungan tiba-tiba, mata merah, kelelahan ekstrem, dan kehilangan bau dan rasa.

\section{PEMBAHASAN}

Menurut Ying-Ying Zheng (2020) kasus Covid-19 pada awal kemunculannya diduga merupakan penyakit pneumonia. Gejala penyakit pneumonia ini serupa sakit flu pada umumnya, seperti batuk, demam, letih, sesak napas, dan tidak nafsu makan. Para ahli kemudian mencatat, misal menurut Fathoni (2019) gejala Covid-19 tidak hanya penyakit pneumonia, tetapi juga beberapa indikasi lain pada tubuh, seperti tubuh merasa sakit, bibir biru, nyeri dada, diare, gejala konjungtivitis atau mata merah muda, kehilangan bau dan rasa, kelelahan, dan sakit kepala. Berdasarkan pendapat para ahli tersebut, gejala Covid-19 yang dibahas dalam tulisan ini berjumlah sembilan leksikon. Kesembilan leksikon tersebut adalah batuk, influenza, pernapasan, sakit perut, bibir dan wajah kebiruan, kebingungan tiba-tiba, mata merah, kelelahan ekstrem, dan kehilangan bau dan rasa.

\section{Leksikon Batuk dalam Bidayuhik}

Dalam beberapa bahasa Bidayuhik leksikon batuk diungkapkan dengan istilah yang bervariasi. Dayak Hibutn di Binjai, Kecamatan Tayan Hulu memiliki leksikon yang sama dengan bahasa Indonesia, tetapi kosakata batuk ini berbeda secara fonetis dengan Dayak Hibutn. Perbedaan fonetis tersebut dapat dilihat melalui variasi bunyi vokal $\mathrm{u} \sim \mathrm{o} / \mathrm{-K} \#$ serta konsonan k R/-\#. Dalam bahasa Indonesia kata tersebut diungkapkan dengan istilah [batuk] sedangkan dalam Dayak Hibutn distilahkan dengan [bato?].

Pada kelompok Bidayuhik yang lain, seperti Dayak Bidayuh, Bakati' Palayo, dan Kerambai leksikon batuk diungkapkan dengan istilah yang sangat berbeda dengan bahasa Indonesia. Artinya, terdapat perbedaan leksikon dalam menamakan penyakit batuk ke dalam tiga bahasa Bidayuhik tersebut. Dalam bahasa Dayak Bidayuh di Kampung Lawang, Kecamatan Siding leksikon batuk diungkap dengan kata [yuak]. Bahasa Dayak Bakati' Palayo leksikon batuk disebut [mukut]. Bahasa Dayak Kerambai di Kampung Masa Selangai istilah batuk diujarkan dengan leksikon [mənkən].

Penyakit batuk ini biasanya menyebabkan juga sakit pada tenggorokan. Leksikon sakit pada tenggorokan ini ternyata diujarkan secara berbeda dalam empat penutur Dayak Bidayuhik yang diteliti. Leksikon sakit tenggorokan ini diungkapkan dalam bentuk gabungan kata dan satu leksem.

Leksikon penamaan penyakit dengan gabungan kata dituturkan oleh Dayak Hibutn, Bakati' Palayo, dan Kerambai, sedangkan satu leksem dituturkan oleh Dayak Bidayuh. Dalam Dayak Hibutn gabungan kata yang muncul adalah [modam tahason]; dalam Dayak Bakati' 
Palayo dinamakan [anap nalat]; dan dalam Dayak Kerambai diistilahkan dengan [manap kuko?]. Adapun leksikon satu leksem untuk istilah sakit tenggorokan diujarkan oleh penutur Bidayuh dari Kampung Lawang, Kecamatan Siding dengan leksikon [tikad]. Perhatikan Tabel 1 Leksikon Gejala Covid-19 (Batuk) dalam Bidayuhik berikut ini.

Tabel 1.

Leksikon 'Batuk' dalam Bahasa-bahasa Bidayuhik

\begin{tabular}{|c|c|c|c|c|}
\hline Leksikon & Hibutn Kpg. Binjai & $\begin{array}{l}\text { Bidayuh Kpg. } \\
\text { Lawang }\end{array}$ & Bakati' Palayo & $\begin{array}{c}\text { Kerambai } \\
\text { Kpg.Masa Selangai }\end{array}$ \\
\hline /batuk/ & [bato?] & [nuak] & [mukut] & [məykən] \\
\hline /batuk berdahak/ & [bato?] & [nuak a:k] & [mukut bra:?] & [məykən bədahak] \\
\hline /batuk darah/ & [bato? doyo] & [yuak iya?] & [mukut daya] & [məykən bədayaw] \\
\hline /batuk kering/ & [bato? haykae] & [nuak bidoh] & [mukut rakeh; seyeh] & [məykən badə] \\
\hline
\end{tabular}

Penyakit batuk ini termasuk indikasi gejala Covid-19. Hal ini terungkap berdasarkan pengamatan Zendrato (2020) biasanya pasien Covid-19 mengalami batuk yang terus-menerus selama lebih dari satu jam atau mengalami batuk rejan selama tiga kali dalam periode 24 jam.

Leksikon batuk memiliki bentuk turunan sebagai variasi dari jenis-jenis penyakit yang berhubungan dengan batuk. Misalnya, batuk berdahak memiliki bentuk gabungan kata, [yuak a:k] pada Dayak Bidayuh; Dayak Bakati’ Palayo menuturkannya dengan istilah [mukut bra:?]; dan dalam Dayak Kerambai dengan istilah [mənkən bədahak], sedangkan dalam Dayak Hibutn direpresentasikan dengan satu leksem [bato?]. Namun, Anggoi dkk (2020) mencatat ada penyakit batuk pilek yang disebut [bato' anyeh] dalam bahasa Hibutn.

Penyakit batuk darah dalam keempat Bidayuhik memperlihatkan leksikon yang berbentuk gabungan kata, yaitu[bato? doyo] dalam Dayak Hibutn; [yuak iya?] dalam Bidayuh Lawang; [mukut daya] dalam Dayak Bakati' Palayo; dan [mənkən bədayaw] dalam Dayak Kerambai. Bentuk gabungan kata batuk darah ini dibentuk dari dua leksikal, yaitu batuk + darah sehingga diterjemahkan ke dalam bahasa Bidayuhik oleh para informan pun menjadi dua kata. Hal ini dapat dibuktikan dalam bahasa Hibutn, misal catatan Asfar (2016) dan Anggoi dkk (2020) leksikon doyo merupakan kosakata tersendiri yang berarti darah. Begitu juga halnya dengan leksikon batuk kering memperlihatkan bentuk gabungan kata dalam empat bahasa Bidayuhik ini. Dalam Dayak Hibutn ini bentuk terjemahannya menjadi [bato? haykae]; dalam Dayak Bidayuh Lawang [yuak bidoh]; dalam Dayak Kerambai menjadi [mənkən badə], sedangkan dalam Dayak Bakati' Palayo memilliki dua bentuk, yaitu leksikon berbentuk gabungan kata [mukut rakeh] dan leksikon yang terdiri atas satu leksem yang disebut [seyeh].

\section{Leksikon Influenza dalam Bidayuhik}

Penyakit influenza dan batuk termasuk gejala Covid-19 yang diindikasikan berbahaya dalam hal menularkan antarmanusia. Hal ini disebabkan media penularan Covid-19 ini bersifat droplet percikan lendir kecil-kecil dari dinding saluran pernapasan seseorang yang keluar saat batuk dan bersin. Oleh karena itu, pemerintah menganjurkan kepada siapa pun yang menderita batuk dan influenza untuk menggunakan masker, tujuannya membatasi percikan droplet dari yang bersangkutan.

Dalam empat bahasa Bidayuhik yang dikaji penyakit influenza memiliki perbedaan penamaan, baik secara fonologi maupun leksikon. Kategori penyakit influenza dalam tulisan ini melingkupi flu, pilek, bersin, hidung tersumbat, dan demam sebagaimana yang digambarkan (Yuliana, 2020) sebagai penyakit gejala Covid-19. Perhatikan Tabel 2 untuk melihat perbedaan leksikon keempat Bidayuhik ini. 
Tabel 2.

Leksikon 'Influenza' dalam Bahasa-bahasa Bidayuhik

\begin{tabular}{|c|c|c|c|c|}
\hline Leksikon & $\begin{array}{c}\text { Hibutn Kpg. } \\
\text { Binjai }\end{array}$ & $\begin{array}{c}\text { Bidayuh Kpg. } \\
\text { Lawang }\end{array}$ & $\begin{array}{c}\text { Bakati' Palayo } \\
\text { Bengkayang }\end{array}$ & Kerambai Kpg.Masa Selangai \\
\hline /flu/ & [anjes] & [mbiniəm] & [enyok] & [ninok] \\
\hline /pilek/ & [anjes] & [ykimuəs] & [babuduk] & [məykətn] \\
\hline $\begin{array}{l}\text { /bersin/ } \\
\text { /hidung } \\
\text { tersumbat/ } \\
\text { /demam/ }\end{array}$ & $\begin{array}{l}\text { [kasei] } \\
\text { [tonduy sumbat] } \\
\text { [monoh] }\end{array}$ & $\begin{array}{l}\text { [pasiopm] } \\
\text { [badog] } \\
\text { [yuah] }\end{array}$ & $\begin{array}{l}\text { [barusut], [rusut] } \\
\text { [duduk ta sunsuk] } \\
\text { [sayoh] }\end{array}$ & $\begin{array}{l}\text { [bəkasi:] } \\
\text { [nu:k badən] } \\
\text { [manəh] }\end{array}$ \\
\hline $\begin{array}{l}\text { /demam } \\
\text { disertai sakit } \\
\text { kepala/ }\end{array}$ & $\begin{array}{l}{[\text { monoh }],[\text { lotik bok }} \\
\text { mondam }]\end{array}$ & [mpajukn] & $\begin{array}{l}\text { [sayoh ge anap } \\
\text { abak] }\end{array}$ & [mayəh səyunaw] \\
\hline
\end{tabular}

Pada penyakit flu perbedaan penamaan secara fonologi dapat dilihat dalam Dayak Bakati' Palayo yang menuturkan kata [eynok] dan dalam Dayak Kerambai menjadi [ninok]. Perbedaan penamaan penyakit flu secara leksikon tampak pada Bidayuhik Hibutn dengan istilah [anjes] dan Bidayuh Lawang dengan istilah [mbiniəm].

Penyakit flu dalam konteks masyarakat kampung dianggap sakit biasa. Namun, penyakit flu saat pandemi Covid-19 tidak bisa dianggap remeh. Hal ini dipertegas oleh Isngadi dkk (2020) bahwa koronavirus biasanya menyebabkan penyakit infeksi saluran pernapasan, mulai dari flu biasa hingga penyakit serius, seperti Middle East Respiratory Syndrome (MERS) dan Severe Acute Respiratory Syndrome (SARS).

Kajian penulis pada masyarakat Bidayuh Lawang memperlihatkan ada istilah penyakit sebelum seseorang terkena pilek. Masyarakat setempat mengenal leksikon penyakit prapilek itu dengan istilah [pilas muəs]. Penyakit ini menyerang pada bagian dalam hidung yang menyebabkan rongga hidung terasa panas. Akibatnya, pernapasan terasa terganggu sehingga menyebabkan kurangnya daya penciuman, bahkan bau yang dicium pun seperti tidak biasa. Malahan, pada saat makan sesuatu hanya terasa di lidah, tetapi tidak bisa mencium aroma makanan tersebut. Dalam konteks penyakit influenza pada bahasa Bidayuh Lawang [pilas mues] biasanya gejala dari akan terjadinya pilek.

Penyakit pilek memperlihatkan perbedaan leksikon antarempat Bidayuhik, misal Dayak Hibutn menyebutnya dengan istilah [anjes], Bidayuh Lawang dengan istilah [økimuəs], Bakati' Palayo menuturkannya dengan sebutan [babuduk], dan Dayak Kerambai menyebutnya dengan istilah [məykətn]. Leksikon bersin menampilkan perbedaan penamaan secara fonologi dalam tiga kelompok Bidayuhik (Hibutn, Bidayuh, dan Kerambai). Ketiga kosakata tersebut jika dibandingkan memperlihatkan perbedaan secara fonologi [kasei] "Hibutn" [pasiopm] "Bidayuh" [bəkasi:] "Kerambai", sedangkan pada Bakati' Palayo ada leksikon [barusut] dan/atau [rusut].

Penyakit hidung tersumbat menampilkan perbedaan leksikon di antara keempat Bidayuhik ini. Contohnya, dalam Dayak Hibutn digunakan bentuk gabungan kata [tonduy sumbat], dalam Dayak Bidayuh dengan istillah [badog], dalam Dayak Bakati' Palayo menjadi [duduk ta sunsuk], dan dalam Dayak Kerambai disebut [nu:k badən].

Leksikon demam termasuk gejala Covid-19 yang menurut Yuliana (2020) memiliki gejala klinis utama suhu badan $>38^{\circ} \mathrm{C}$. Lebih lanjut Yuliana menjelaskan bahwa pada pasien Covid19 yang lanjut usia dan pasien immunocompromises presentasi gejala menjadi tidak khas atau atipikal. Selain itu, pada beberapa kasus ditemui tidak disertai dengan demam dan gejala relatif ringan. Mahrania dkk (2020) juga mencatat bahwa pasien Covid-19 pasien yang diukur dengan termometer aksila) pada pagi hari $37,5^{\circ} \mathrm{C}$, pada sore hari $37,8^{\circ} \mathrm{C}$, dan pada dini hari $38,8^{\circ} \mathrm{C}$ disertai demam, mual, dan lemas terus berlangsung selama 8 hari 
Leksikon demam ini dalam keempat Bidayuhik ini memperlihatkan perbedaan secara fonologi. Dalam Dayak Hibutn disebut penyakit [mojoh], Dayak Bidayuh menyebutnya [ỹuah], Dayak Bakati' Palayo menuturkannya dengan istilah [sayoh], dan Dayak Kerambai menyebutnya dengan istilah [mayəh]. Dalam Dayak Hibutn leksikon [moyoh] bervariasi dengan [mayəh] dalam Dayak Kerambai. Variasi bunyi vokal di antara konsonan ini memperlihatkan bunyi o-o a-ə/\#K_K\#.

Bahasa Bidayuhik juga memperlihatkan leksikon demam yang disertai sakit kepala. Hal ini dapat dilihat dalam masyarakat Dayak Bidayuh Lawang, leksikon tersebut diistilahkan dengan [mpajukn]. Dalam Dayak Hibutn, Bakati' Palayo, dan Kerambai istilah ini dituturkan dengan gabungan kata, yaitu pada Dayak Hibutn disebut [lotik bok mondam], Dayak Bakati' Palayo dengan istilah [sayoh ge anap abak], dan Dayak Kerambai menyebutnya dengan istilah [mayəh səyunaw].

\section{Leksikon Penyakit Pernapasan dalam Bidayuhik}

Leksikon penyakit pernapasan yang mengindikasikan Covid-19 adalah sesak napas dan napas pendek serta diikuti dengan rasa sakit di dada. Menurut Yuliana (2020) setengah dari pasien Covid-19 timbul sesak dalam satu minggu. Pada kasus berat perburukan secara cepat dan progresif, seperti ARDS, syok septik, asidosis metabolik yang sulit dikoreksi dan perdarahan atau disfungsi sistem koagulasi dalam beberapa hari.

Sesak napas dalam bahasa Bidayuhik diungkapkan dengan bentuk satu leksem dan gabungan kata. Bentuk satu leksem tampak dalam Dayak Bakati' Palayo yang diungkapkan dengan istilah [sina?] berarti 'sesak napas'. Bentuk gabungan kata terdapat dalam masyarakat Dayak Hibutn dengan istilah [puah yasong] dan [sosok penason] untuk menjelaskan sakit 'sesak napas'. Dayak Bidayuh Lawang penyakit sesak napas dikenal istilah [got hamsoky] dan Dayak Kerambai menyebutnya dengan istilah [sakət asək]. Perhatikan Tabel 3 berikut ini.

Tabel 3.

Leksikon 'Penyakit Pernapasan' dalam Bahasa-bahasa Bidayuhik

\begin{tabular}{|c|c|c|c|c|}
\hline Leksikon & $\begin{array}{c}\text { Hibutn Kpg. } \\
\text { Binjai }\end{array}$ & $\begin{array}{c}\text { Bidayuh Kpg. } \\
\text { Lawang }\end{array}$ & $\begin{array}{c}\text { Bakati' Palayo } \\
\text { Bengkayang }\end{array}$ & $\begin{array}{c}\text { Kerambai } \\
\text { Kpg.Masa Selangai } \\
\end{array}$ \\
\hline /sesak napas/ & $\begin{array}{l}\text { [puah yasong]; } \\
\text { [sosok penason] }\end{array}$ & [got hamsokn] & [sina?] & [sakət asək] \\
\hline /napas pendek/ & [kidik pengasong] & [eggot masokn] & [sinat-sinat] & [kidək asək] \\
\hline
\end{tabular}

Sesak napas dalam bahasa Bidayuhik ini berarti merujuk pada sakit kesulitan bernapas. Bahkan, dada terasa sesak diikuti dengan napas yang sengal-sengal. Penyakit ini menyebabkan orang yang mengalaminya kesulitan pada saat bernapas seakan-akan dadanya terasa penuh dengan kesesakan. Sesak napas termasuk gejala Covid-19 yang paling lazim menyebabkan kematian. Hal ini bisa dilihat dari laporan (Luciano dkk, 2020) di Italia Utara bahwa jumlah pasien penderita pernapasan akut banyak diterima di ICU.

Catatan Anggoi dalam masyarakat Hibutn yang ada di Kecamatan Parindu mengenai leksikon napas memperlihatkan perbedaan secara fonologi dengan Hibutn yang ada di Binjai, Kecamatan Tayan Hulu. Anggoi mencatat leksikon [asakng] yang berarti 'napas'. Kata turunan bentuk ini adalah [yasaky] 'bernapas' dan [puyasaky] 'pernapasan'. Contoh dalam kalimat lema puyasaky adalah jeh potikpuyasakynyo to 'sudah habis pernapasan orang ini' (Anggoi dkk, 2020).

Dalam bahasa Bakati' Palayo leksikon napas disebut [sinat], sedangkan penyakit sesak napas disebut [sina?]. Kata turunan leksikon singat ini adalah basingat, nyingat, mensingat. Selain itu, ada juga leksikon sesak napas bukan penyakit, dalam konteks menangis, yaitu leksikon sikal. Leksikon ini bermakna menangis yang sudah tidak mampu ditahan lagi seperti 
orang sesak napas, missal sampe sikal kangot koh munse 'sampai sesak (napas) anak itu menangis'.

\section{Leksikon Sakit Perut dalam Bidayuhik}

Sakit perut dan diare merupakan gejala Covid-19 yang dialami pasien koronavirus. Hal ini berdasarkan pengamatan Mahrania dkk, (2020) yang mencatat ada juga pasien Covid-19 mengalami sakit perut dan buang air besar (cair) tiga kali (tanpa lendir, tanpa darah. Leksikon penyakit sakit perut ini dalam bahasa Bidayuhik dituturkan dengan gabungan kata. Hasil kajian data yang ada dalam masyarakat Dayak Hibutn leksikon sakit perut disebut [mondam tonik], sedangkan varian Hibutn yang ada Parindu menuturkannya dengann [monapmtonikng] (lihat Anggoi dkk, 2020). Dalam Dayak Bidayuh Lawang sakit perut disebut [minapmtimuaky], dalam Dayak Bakati' Palayo diistilahkan [anapputuk], dan dalam Dayak Kerambai disebut [manapputuk].

Leksikon penyakit diare dalam keempat bahasa Dayak Bidayuh yang diteliti memperlihatkan tuturan berbentuk gabungan kata dan satu leksem. Pertama, tuturan leksikon diare yang berbentuk gabungan kata terdapat dalam Dayak Bakati' Palayo dengan menggunakan istilah [makemansur]. Kedua, leksikon diare yang direpresentasikan dengan satu leksem wujud dalam Dayak Hibutn, Bidayuh Lawang, dan Kerambai. Masyarakat Dayak Hibutn mengenal istilah [pancih] untuk mengartikan diare. Dalam Dayak Bidayuh Lawang diare disebut [yasual], sedangkan dalam Dayak Kerambai disebut [nancos]. Perhatikan Tabel 4 berikut ini.

Tabel 4.

Leksikon 'Sakit Perut' dalam Bahasa-bahasa Bidayuhik

\begin{tabular}{|c|c|c|c|c|}
\hline Leksikon & $\begin{array}{c}\text { Hibutn Kpg. } \\
\text { Binjai }\end{array}$ & $\begin{array}{c}\text { Bidayuh Kpg. } \\
\text { Lawang }\end{array}$ & $\begin{array}{c}\text { Bakati' Palayo } \\
\text { Bengkayang }\end{array}$ & $\begin{array}{c}\text { Kerambai Kpg.Masa } \\
\text { Selangai }\end{array}$ \\
\hline /sakit perut/ & $\begin{array}{l}\text { [mondam } \\
\text { tonik] }\end{array}$ & [minapm timuaky] & [anap putuk] & [manap putuk] \\
\hline /diare/ & [pancih] & [nasual] & [make mansur] & [yajcos] \\
\hline
\end{tabular}

Leksikon penyakit diare ini dikenal juga dengan istilah penyakit muntaber dalam terminologi masyarakat lokal. Penyakit muntaber ini dalam beberapa kasus menyerang pasien koronavirus. Hal ini sejalan dengan pendapat Yuliana yang mencatat gastrointestinal atau muntaber sebagai gejala Covid-19 pada pasien koronavirus (Yuliana, 2020).

Sakit perut ini dalam bahasa Bidayuhik juga muncul dengan istilah lain, seperti penyakit [ykola] dalam Dayak Hibun yang merujuk makna pada sakit mag. Sakit mag ini dalam Dayak Bidayuh Lawang dan Kerambai disebut [mah]. Dalam masyarakat Bakati' Palayo sakitmag diungkapkan dengan gabungan kata yang bervariatif, misal ada sakit [anap baba ate] yang merujuk pada rasa sakit pada "ulu hati" dan ungkapan [anap tara duykat] yang merujuk pada sakit disebabkan "asam lambung".

Penamaan rasa sakit pada perut juga memiliki variasi yang beragam pada Dayak Hibutn. Anggoi mencatat ada leksikon mulah sebagai kosakata yang menjelaskan keadaan perut yang terasa sakit. Selain itu, Anggoi dkk juga mencatat leksikon ngkolau yang bermakna sakit mag atau sakit perut yang disertai mual-mual. Misal, pada kalimat ngkolauoti ko mosi' duo' buoh jamu'perutku terasa mual setelah memakan buah jambu' (Anggoi dkk, 2020).

\section{Leksikon Gejala Covid-19 Lain dalam Bidayuhik}

Ada lima gejala Covid-19 lainyang diungkapkan untuk diketahui dalam konteks penamaan lokal bahasa Bidayuhik, seperti bibir dan wajah kebiruan, kebingungan tiba-tiba, mata merah muda, kelelahan ekstrem, dan kehilangan bau dan rasa. Lebih lanjut Fathoni menjelaskan rasa sakit yang terus-menerus atau tekanan di dada serta bibir dan wajah kebiruan 
mengindikasikan seseorang sedang kekurangan oksigen (Fathoni, 2019). Perhatikan Tabel 5 untuk perbandingan leksikon lima gejala Covid-19 lainnya berikut.

Tabel 5.

Leksikon Gejala Covid-19 lainnya dalam Bahasa-bahasa Bidayuhik

\begin{tabular}{|c|c|c|c|c|}
\hline Leksikon & $\begin{array}{c}\begin{array}{c}\text { Hibutn Kpg. } \\
\text { Binjai }\end{array} \\
\end{array}$ & $\begin{array}{c}\begin{array}{c}\text { Bidayuh Kpg. } \\
\text { Lawang }\end{array} \\
\end{array}$ & $\begin{array}{c}\text { Bakati' Palayo } \\
\text { Bengkayang }\end{array}$ & $\begin{array}{c}\text { Kerambai } \\
\text { Kpg.Masa Selangai }\end{array}$ \\
\hline $\begin{array}{l}\text { /bibir dan wajah } \\
\text { kebiruan/ }\end{array}$ & $\begin{array}{l}\text { [selombih yan jowi } \\
\text { biru] }\end{array}$ & [bi:h jiwine:] & [bibis banarup] & [bibih yan jowi biyu] \\
\hline $\begin{array}{l}\text { /kebingungan tiba- } \\
\text { tiba/ }\end{array}$ & [keyayok] & [mami?] & [rue],[ruhe],[ruwe] & [linaw] \\
\hline /mata merah/ & [motuh ntocok] & [bitotn bləh] & [matu bajara] & [batəh bədayaw] \\
\hline /kelelahan ekstrem/ & [lopo pehabis] & [m:a?] & [mayuh] & [kuyoh luwa: biaso] \\
\hline $\begin{array}{l}\text { /kehilangan bau dan } \\
\text { rasa/ }\end{array}$ & [moyok buh yay aso] & [madoy] & [kapul] & [bodu] \\
\hline
\end{tabular}

Pertama, leksikon penyakit bibir dan wajah kebiruan dalam bahasa Bidayuhik dibentuk dengan gabungan kata, misal dalam Dayak Hibutn diujarkan [selombih yan jowi biru]. Selanjutnya, Dayak Bidayuh Lawang menyebutnya dengan istilah [bi:h jiwine:], dalam Bakati‘ Palayo disebut [bibis banarup], dan dalam Dayak Kerambai diujarkan [bibih yan jowi biyu].

Kedua, leksikon kebingungan tiba-tiba dalam keempat bahasa Bidayuhik yang diteliti memperlihatkan empat leksikon yang berbeda. Dalam Dayak Hibutn istilah ini disebut [keyayok], dalam Dayak Bidayuh Lawang disebut [mami?], dalam Dayak Bakati‘ Palayo diujarkan dengan kata [rue], [ruhe], dan [ruwe], sedangkan dalam Dayak Kerambai diistilahkan dengan [linaw]. Menurut Fathoni (2019), sakit yang mengindikasikan kebingungan yang tibatiba merupakan tanda serius bahwa perawatan darurat diperlukan dan haruscepat mencari bantuan.

Ketiga, leksikon mata merah dalam bahasa Bidayuhik diungkapkan dengan bentuk gabungan kata. Dayak Hibutn mengungkapkan leksikon ini dengan istilah [motuh ntocok]. Dayak Bidayuh Lawang mengujarkannya dengan istilah [bitotn bləh]. Dayak Bakati` Palayo menyebutnya dengan istilah [matu bajara], sedangkan Dayak Kerambai dengan istilah [batəh bədayaw]. Menurut Fathoni (2019), penderita mata merah muda 'konjungtivitis' merupakan gejala Covid-19 terjadi pada sekitar 1\% hingga 3\% orang penderita di Cina, Korea Selatan, dan bagian lain dunia. Namun, mata merah muda atau merah bisa menjadi satu tanda lagi bahwa juga memiliki gejala Covid-19 lainnya, seperti demam, batuk, atau sesak napas.

Keempat, leksikon kelelahan ekstrem dalam bahasa Bidayuhik diujarkan dalam bentuk gabungan kata dan satu leksem. Bentuk gabungan kata terdapat dalam bahasa Dayak Hibutn dengan istilah [lopo pehabis] dan Dayak Kerambai dengan istilah [kuyoh luwa: biaso]. Bentuk satu leksem diungkapkan dalam Dayak Bidayuh Lawang dengan istilah [m:a?] dan Dayak Bakati‘ Palayo dengan istilah [mayuh]. Fathoni (2019) melaporkan kelelahan ekstrem bisa menjadi tanda awal terinfeksi koronavirus. Laporan WHO mencatat 40\% dari 6.000 orang dengan kasus yang dibuktikan melalui laboratorium menderita kelelahan.

Kelima, leksikon kehilangan bau dan rasa dituturkan dalam bentuk gabungan kata pada Dayak Hibutn dengan istilah [moyok buh yay aso]. Leksikon ini dalam tiga bahasa Bidayuhik lain disebut dengan satu leksem, seperti Bidayuh Lawang menyebutnya dengan istilah [madoy]. Selanjutnya, dalam Dayak Bakati‘ Palayo disebut [kapul] dan dalam Dayak Kerambai disebut [bodu]. Fathoni (2019) mencatat pada kasus koronavirus yang ringan hingga sedang, hilangnya bau dan rasa muncul sebagai salah satu tanda awal Covid-19 yang paling tidak biasa. Kasuskasus ringan di Korea Selatan menemukan gejala utama pada $30 \%$ pasien adalah hilangnya penciuman.

\section{PENUTUP}

Penelitian ini menjabarkan leksikon gejala Covid-19 dalam bahasa-bahasa Bidayuhik di Kalimantan Barat. Leksikon gejala Covid-19 ini ada yang berbentuk gabungan kata dan ada 
yang terdiri atas satu leksem. Selain itu, penelitian ini berhasil mendokumentasikan empat bahasa Dayak yang terklasifikasi dalam kelompok Bidayuhik dalam penamaan gejala-gejala Covid-19.

Penelitian ini pun berhasil memetakan perbedaan leksikon dalam mengidentifikasi gejala Covid-19. Bahkan, perbandingan keempat bahasa Bidayuhik dalam penelitian ini mengidentifikasi tidak hanya perbedaan leksikon, tetapi juga perbedaan secara fonologi. Penelitian ini mendeskripsikan persebaran bunyi dan leksikon bahasa Bidayuhik yang ada di Kalimantan Barat berkenaan dengan gejala Covid-19. Penelitian ini menyibak pengetahuan lokal berkenaan dengan leksikon gejala Covid-19 dalam bahasa Bidayuhik di Kalimantan Barat. Alhasil, leksikon ini memperlihatkan daya ungkap jenis-jenis penyakit pada bahasa Bidayuhik. Dengan demikian, leksikon gejala Covid-19 bahasa Bidayuhik ini dapat dipertimbangkan masuk dalam Kamus Besar Bahasa Indonesia sebagai pengayaan kosakata berbasis bahasa daerah. Selain itu, penelitian ini berkontribusi bagi tenaga kesehatan yang berhubungan langsung dengan penutur Bidayuhik di Kalimantan Barat untuk menggunakan istilah lokal tersebut dalam menyosialisasikan gejala Covid-19 kepada masyarakat.

\section{DAFTAR PUSTAKA}

Aida, N. R. (2020). 10 Gejala Kunci Terinfeksi Virus Corona, Tetap Waspada karena Covid-19 Belum Reda. www.kompas.com. https://www.kompas.com/tren/read/2020/04/17/064000065/10-gejalakunci-terinfeksi-virus-corona-tetap-waspada-karena-covid-19-belum?page=all\#page4

Almos, R. dan P. (2015). Leksikon Etnomedisin dalam Pengobatan Tradisional Minangkabau. Jurnal Arbitrer, 2(1), 44-53. https://doi.org/10.25077/ar.2.1.44-53.2015

Anggoi, Bernardus, D. (2020). Kamus Bahasa Hibutn-Indonesia. Dinas Perpustakaan dan Kearsipan Provinsi Kalimantan Barat.

Asfar, D. A. (2014). Klasifikasi Bahasa Dayak Pruwan sebagai Bahasa Bidayuhik. Jurnal KANDAI, 10(2), 138-152. https://doi.org/https://dx.doi.org/10.26499/jk.v10i2.318

Asfar, D. A. (2015). Kekerabatan dan Pemetaan Bahasa-Bahasa Dayak di Tayan Hulu. Elmatera.

Asfar, D. A. (2016). Ciri-Ciri Bunyi Bahasa Bemak. In D. A. Shin, Chong; Carruthers, Andrew M.; Asfar (Ed.), Bukit Sama Didaki, Festhchrift Sempena Hari Lahir Profesor Emeritus Dr. James T. Collins yang ke-70 (pp. 13-27). Institut Kajian Etnik, Universiti Kebangsaan Malaysia.

Chong Shin. (2008). Bahasa Bidayuhik di Borneo Barat. Dewan Bahasa dan Pustaka.

Chong Shin dan Collins, J. T. (2008). Tinjauan Varian Bidayuhik di Lembah Sekadau. In C. Shin (Ed.), Bahasa Bidayuhik di Borneo Barat (pp. 1-24). Dewan Bahasa dan Pustaka.

Collins, J. T. (2021). Keberagaman Bahasa dan Etnisitas di Kalbar. Indonesia Melestarikan Bahasa Ibu (ILBI).

Crystal, D. (2008). A Dictionary of Linguistics and Phonetics 6th Edition (6th ed.). Blackwell Publishing. https://doi.org/10.1002/9781444302776

Fathoni, A. (2019). Dampak Covic 19 dan Kebijakan PSBB Pemerintah terhadap UMKM di Wiyung, Surabaya. Dinar Jurnal Prodi Ekonomi Syari'ah, 3(1), 30-69. http://ejurnal.stail.ac.id/index.php/dinar/article/view/126

Fatmawaty, dkk. (2018). Penamaan Penyakit pada Anak oleh Etnis Bugis (Studi Rapid Ethnography di Kabupaten Sidrap). Digilib.Unhas.Ac.Id. http://digilib.unhas.ac.id/uploaded_files/temporary/DigitalCollection/YjdlNDQ3NjZkNzRhMTNkNWI1 YmY2OGMzMDQ3N2RiZWQxN2IyZT MOMA

Fuadah, N. (2016). Istilah-istilah Penyakit Kulit dan Kelamin pada Masyarakat Jawa di Desa Tegal Pare Kecamatan Muncar Kabupaten Banyuwangi (Tinjauan Semantik dan Etimologi). Universitas Jember.

Isngadi, dkk. (2020). Tatalaksana Anestesi pada Operasi Obstetri dengan Covid-19. Jurnal Anastesi Obstetri Indonesia, 3(1), 35-46. https://doi.org/10.47507/obstetri.v3i1.41

Luciano, Gattinoni, D. (2020). COVID-19 Does Not Lead to a "Typical" Acute Respiratory Distress Syndrome. American Journal of Respiratory and Critical Care Medicine, 201(10), 1299-1300. 
https://doi.org/10.1164/rccm.202003-0817LE

Mahrania, dkk. (2020). Kasus COVID-19 Ringan pada Tenaga Medis: Evaluasi Temuan Klinis dan Risiko Transmisi. Journal Indonesia Medicine Association, 70(4), 78-86. https://doi.org/10.47830/jinma-vol.70.4-2020-223

Pratiwi, Ericha, W. (2020). Dampak COVID-19 Terhadap Kegiatan Pembelajaran Online di Sebuah Perguruan Tinggi Kristen di Indonesia. Perspektif Ilmu Pendidikan, 34(1), 1-8. https://doi.org/10.21009/PIP.341.1

Raco, J. R. (2010). Metode Penelitian Kualitatif Jenis, Karakteristik, dan Keunggulannya. Grasindo.

Rensch, C. R., D. (2012). The Bidayuh Language Yesterday, Today, and Tomorrow. SIL e-Books.

Sakinah. (2016). Leksikon Nama Penyakit dalam Bahasa Melayu Dialek Sekadau. Universitas Tanjungpura.

Sari, dkk. (2020). Hubungan antara Pengetahuan Masyarakat dengan Kepatuhan Penggunaan Masker sebagai Upaya Pencegahan Penyakit COVID-19 di Ngronggah. INFOKES, 10 (1), 52-55. https://doi.org/10.47701/infokes.v10i1.850

Spolsky, B. (ed. . (1999). Concise Encyclopedia of Educational Linguistic. Cambridge University Press.

Ying-Ying Zheng, dkk. (2020). COVID-19 and the Cardiovascular System. Nat Rev Cardiol, 17, 259260. https://doi.org/10.1038/s41569-020-0360-5

Yuliana. (2020). Coronavirus Diseases (COVID-19): Sebuah Tinjauan Literatur. WELLNESS AND HEALTHY MAGAZINE, 2(1), 187-192. https://doi.org/10.30604/well.95212020

Zaim, M. (2014). Metode Penelitian Bahasa: Pendekatan Struktural. Penerbit FBS UNP Press.

Zendrato, W. (2020). Gerakan Mencegah daripada Mengobati terhadap Pandemi COVID-19. Jurnal Education and Development, 8(2), 242-248.

Zhe Xu, dkk. (2020). Pathological Findings of COVID-19 Associated with Acute Respiratory Distress Syndrome. Lancet Respir Med, 8(4), 420-422. https://doi.org/doi.org/10.1016/S22132600(20)30076-X. 